\title{
Otto neurath's relevance FOR SCIENCE POLICY DEBATES
}

\author{
Reiner Grundmann - \\ PhD, Professor. \\ School of Sociology \\ and Social Policy, \\ University of Nottingham. \\ Nottingham NG7 2RD, UK; \\ e-mail: reiner.grundmann@ \\ nottingham.ac.uk
}

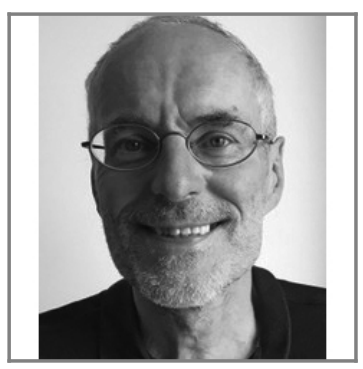

Debates about the role of science in policy making have highlighted the uneasy relationship between knowledge and decision making. Recent high-profile examples include climate change and the COVID-19 pandemic. On the one hand there is an intertwinement between facts and values. On the other hand, there is a tension between the acknowledgement of scientific uncertainty and the justification of political action. This sometimes finds political solutions that are perceived as unsound and unsatisfactory. Some perceive the policies as too weak, some as too strong. Both appeal to fundamental values such as health, wealth, security, freedom, equality, or solidarity. In this article I will argue that we need a more open debate about these issues and a deeper understanding of what is at issue in science policy debates. I shall do so by referring to a Neurathian framework. Neurath's legacy survives mainly in the history and philosophy of science but is largely forgotten in policy studies and sociology. This needs rectifying, especially in light of the fact that he anticipated central insights that have been attributed to later authors such as Fleck and Kuhn.

The paper has the following structure. I first provide some historical and intellectual context by looking at the Vienna Circle and some biographical background about Neurath's views, and his political engagement. I then examine his epistemology, especially his view of science and the social sciences, leading to his antifoundationalism. Finally, I turn to the public policy literature which has produced results that partly overlap with, and partly contradict Neurath's views.

Keywords: Neurath, climate science, policy making, IPCC, scientific uncertainty, scientific consensus

\section{З НАЧЕНИЕ ИДЕЙ О. НЕЙРАТА ДЛЯ ДИСКУССИЙ О НАУЧНОЙ ПОЛИТИКЕ}

\author{
Райнер Грундманн - доктор \\ философии, профессор. \\ Школа социологии \\ и социальной политики \\ Ноттингемского \\ университета. \\ Ноттингем, NG7 2RD, \\ Великобритания; \\ e-mail: reiner.grundmann@ \\ nottingham.ac.uk
}

\begin{abstract}
Дебаты о роли науки в политической практике выявили непростую связь между знанием и принятием решений. Недавние громкие примеры включают изменение климата и пандемию COVID-19. С одной стороны, в них переплетаются факты и ценности. С другой стороны, имеет место противоречие между признанием научной неопределенности и оправданием политических действий. Иногда это противоречие находит политическое решение, которое воспринимается как необоснованное и неудачное. Одни считают политику слишком слабой, другие - слишком сильной. И обе стороны взывают к базовым ценностям, таким как здоровье, благополучие, безопасность, свобода, равенство или солидарность. В этой статье я утверждаю, что нам нужно более открытое обсуждение данных вопросов и более глубокое понимание того, что именно должно быть в фокусе дебатов о научной политике. Я использую здесь концептуальные рамки философии О. Нейрата. Наследие
\end{abstract}


Нейрата сохранилось в основном в истории и философии науки, но по большей части забыто в социологии и политологии. Это нуждается в коррекции, особенно в свете того, что принципиальные инстайты, приписанные более поздним авторам, вроде Л. Флека и Т. Куна, по сути принадлежат О. Нейрату.

Ключевые слова: Нейрат, климатология, политика, научная неопределенность, научный консенсус

\section{Otto Neurath and the Transformation of Society by Science}

Decades before Thomas Kuhn revolutionized the way we perceive the production of scientific knowledge a key debate had been started within the philosophy of science by a group of philosophers and social scientists known as the Vienna Circle. Founded in the early 1920s its members included, among others, Moritz Schlick, Hans Hahn, Rudolf Carnap and Otto Neurath. In 1929 the Verein Ernst Mach was founded and served as an organizational framework for the activities of the circle. In the same year the programmatic statement Wissenschaftliche Weltauffassung - Der Wiener Kreis was published at a conference in Prague. The Vienna group established connections to scholars in Berlin (Reichenbach, Hempel, Hilbert) and many other countries, among them Poland, the USA, and England. The activities of this group dominanted philosophical thought over the years to come in many ways (see [Hegselmann, 1979] for an overview) $)^{1}$.

Comparing the standstill of philosophy with the quick development and practical success of the sciences, the members of the Vienna Circle set out to emulate the secrets of their success. This became known under the name Logical Empiricism, a programme, with the aim of creating a unity of science, which soon turned into a battle cry. It meant to provide criteria by which competing philosophical systems could be compared and tested. The recipe was simple enough: sift through knowledge claims and statements (philosophical theories and systems of thought) and decide if these are true or false. Only meaningful statements could be tested in this way which means that there is a third category of statements that are meaningless (so-called pseudo-statements). This process is one of clarification (Klärung, note the connotation to 'purification' in German). The task of the philosopher is not to come up with new statements (too many have been produced already) but to clarify existing ones. While I cannot do justice to the principles and practice of the Vienna Circle, it

1 I have quoted from an English translation of [Hegselmann, 1979] which was produced by Marie Neurath but has not been published. I am grateful to Rainer Hegselmann for providing me with a copy. 
seems commonly accepted that later developments led to a ramification of positions and eventual demise of the enterprise.

Among the members of the Vienna Circle Otto Neurath deserves special attention. He was involved both with theoretical questions of the foundations of scientific knowledge and practical questions in public policy. A contemporary of Max Weber and student of Schmoller, Neurath was immersed in the theoretical and political debates of the time. He was advisor to government in the aftermath of the German revolution 19181919. In this instance he tried to develop an economic policy both for war and peace times. Besides, he is the inventor (together with his wife Marie Neurath) of visual methods to represent statistical data (ISOTYPES, Wiener Bildstatistik). He was active in adult education and the running of museums.

In early 1919 Neurath was appointed by the revolutionary government in Bavaria as president of the Central Economic Office. In this function he believed to be able to oversee the socialization of the Bavarian economy within five to ten years. Interestingly, he insisted that he was an unpolitical civil servant who tries to put economic policies into practice without being involved in the ongoing political battle about the future of the political institutions. After this intermezzo he was charged and prosecuted by a court martial (Standgericht) for his role in the revolutionary government.

Neurath served under three different govenments during the Bavarian revolution. These were the Imperial-and-Royal war ministry (K\&K Kriegsministerium), a bourgeois-socialist coalition government, and a Soviet republic. As Otto Bauer put it when giving evidence in his defence at the Standgericht, 'Neurath recommends a planned order and rearrangement of economic life from above through an administration standing over the society, and it is not interesting to him whether that is an Imperial-and-Royal war ministry, a democratic parliamentary government or a soviet dictator' (quoted in [Cartwright et al., 1996, p. 230]).

'Neurath saw the task of the theory of war economy in the investigation of the effects which wars and war preparations exert on the wealth of men. He stressed that the theory of war economy is a science "like ballistics which is independent of the fact whether one advocates the use of guns or not"' (quoted in [Hegselmann, 1979, pp. 20-21]; the Neurath source is a text published in 1919 under the title Durch die Kriegswirtschaft zur Naturalwirtschaft).

Furthermore, Neurath saw the massive planning and organizational efforts during the war as a model of rational organization of society in peace times. Elements of central planning were essential and Neurath had high hopes in using economic instruments produced by the war for enhancing the living conditions in peacetimes. 


\section{Neurath's Politics}

Neurath envisaged a moneyless economy in which goods would be distributed through central command and planning. Markets had no place in such a scheme [Cartwright et al., 1996, p. 37]. Max Weber called his views on economic management 'amateurish'. Like Otto Bauer, Weber had given testimony at the court martial in Neurath's favour. However, in a private letter to Neurath he accused him of 'irresponsible foolishness that could discredit socialism for a hundred years' (cited in [Cartwright et al., 1996, p. 54]).

Regarding the potential of science and technology Neurath was optimistic to a degree of Prometheanism, reminiscent of Bacon, Hobbes, Vico and Marx when he embraced the 'new spirit' according to which 'everything that can be technically managed should be formed according to general principles, as successfully as possible, as rationally as possible... everything will become transparent and manageable'. This approach would come to dominate not only economic and organizational aspects of social life: 'We have just arrived at the conviction that an immense part of our order of life can be formed purposefully, that especially consumption and production can be determined and regulated quantitatively, even if we are not yet able or willing to regulate customs and morals, religion and love' (cited in [Hegselmann, 1979, p. 32]) ${ }^{2}$.

We may be taken aback by such views, suspecting an ever-increasing interference of state surveillance with private affairs. However, writing at the end of the First World War this was an astute prophesy about things to come, many of which we now take for granted. We still abhor the totalitarian overtones of central planning but likewise shun the consequences of unfettered market liberalism. As the financial crisis after 2008 exemplifies, bringing our life under rational control is still the modern conviction and promise at the heart of western democracies.

There is another aspect that deserves comment. Neurath happily adopted the label of a social engineer. His attempts to develop a planned economy went hand in hand with his endeavors to advance the unity of science. Writing in 1919, he proclaimed:

'A social engineering construction treats our whole society and above all our economy in a way similar to a giant concern. The social engineer who knows this work and wants to provide a construction that will

$2 \quad$ As Cartwright et al. [1996, pp. 3, 92] put it: 'Although [Neurath] was a pluralist about knowledge systems and took seriously their historical and cultural roots, he trusted firmly in the power of science. Not science on its own as an abstract system of thought, but science in the hands of the social technician, who can "orchestrate" the different systems of knowledge to build new social orders... He was a man of the Enlightenment, fired by an idea simple in conception, yet difficult to realize: to develop and employ a conception of knowledge as an instrument of emancipation'. 
be usable for practical purposes as a first lead, must pay equal attention to the psychological qualities of men, to their love of novelty, their ambitions, attachment to tradition, wilfulness, stupidity - in short to everything peculiar to them and definitive of their social action within the framework of the economy, just as the engineer must pay attention to the elasticity of iron, to the breaking point of copper, the color of glass and to other similar factors' (cited after [Cartwright et al., 1996, p. 176]).

Neurath thought that the project of socialization in the aftermath of WWI was possible because he thought that the state of science and technology (and their unified character) made possible such practical attempts at restructuring the economy. Political leaders would be able to draw upon the work of social engineers. In this context he seems to utter the credo of the technocratic world view when he proclaims: 'Metaphysical terms divide; scientific terms unite ([Neurath, 1933, p. 28] quoted after the translation in [McGuinness, 1987, p. 23]). He seems to be saying that ideological battles in society, based on metaphysical convictions can be avoided through a science-based approach. But Neurath applies this line of thought to the inner workings of the sciences, he does not advocate science should dominate society ${ }^{3}$ :

'Strict self-discipline is needed... one must renounce all those fashionable catchwords that people love to use just because they are there... Strict self-control leads to successful cooperation between scientific specialists in the most diverse fields. Metaphysical terms divide - scientific terms unite. Scientists, united by a unified language, form a kind of workers' republic of letters, no matter how much else may divide them as men' (cited in [McGuinness, 1987, p. 23]).

This was written one year before the first world war. After it had ended, Neurath was actively involved in developing a new economy, based on comprehensive state planning. As Cartwright et al. argue convincingly, Neurath's view was that the complexity of social and economic relations required the full understanding of all its different aspects. The unity of science now becomes central to the political project of building a new economic system [Cartwright et al., 1996, pp. 176-177]. I will return below to the question of social engineering, and the influence of science on policy making. The unity of science means above all, to develop a common language to describe topics of common interest, as O'Neill has pointed out:

The project of the unity of science movement was social project, that of co-ordinating the activities and output of the scientific community, in part as a means of co-ordinating knowledge for social decision making. The aim of the project was the realisation of the co-ordination of different disciplines. Any decision about particular states of affairs would draw

3 See also [O'Neill, 2003] who holds that it would be a mistake to conclude from this that Neurath was espousing technocratic world view. 
upon different sciences. This problem was central to any possibility of social planning which calls on a variety of forms of knowledge [O'Neill, 2003, p. 579].

Empirical sociology was important to Neurath as it offered a tool for political intervention and planning. Because he had an interest in intervention and planning he wanted to test sociological statements and subject them to tests of intersubjectivity. He disagreed sharply with Weber's principles of interpretive sociology (verstehende Soziologie), especially his notions of intuition and empathy. But Neurath did not go so far as to juxtapose the sciences as providing 'truth' or universal laws on the one hand and the social sciences as being left to provide interpretations, as I will show below (section 'Science and Social Practice').

\section{Neurath's Epistemology}

It is often claimed that Neurath objected to a correspondence theory of truth, and that he argued in favour of a coherence theory of truth. He rejected this description since he did not believe in theories of truth at all. The coherence principle states that one cannot compare statements with reality but only with other statements. It does not tell us about reality or truth. As he put it, 'statements are compared with statements, not with "experiences", not with a world nor with anything else. All these meaningless duplications belong to a more or less refined metaphysics, and must be rejected' ([Neurath, 1932, p. 403], cited after [Cartwright et al., 1996, p. 183]).

Turning to his contribution to epistemology, it has to be noted how far reaching his contribution was, albeit little recognized 4 . His foremost concern was the quest for a non-metaphysical science. This means, quite literally, to exclude anything from scientific (and political) debate that is not located in space and time. Only events and objects that are 'physical' in this sense should be allowed to be topics of debate [Neurath, 1931].

Very much in line with Duhem and Quine he also rejects the simplistic view that an isolated test of a hypothesis would be possible as this overlooks the important part played by background assumptions. Therefore, Popper's idea of an experimentum crucis which would decide about the truth or falsity of a theory must be rejected. Drawing on the distinction between observation and protocol statements (common to the members of the Vienna Circle) he claimed that both were open to revision. In other words, there exist no secure foundations for science, neither

$4 \quad$ I should note in passing that Neurath did not embrace the term epistemology, he rather preferred to speak about 'the science of science'. 
in terms of theories nor in terms of observations. Hence his metaphor of the boat at sea that needs repairing away from the safe dock ${ }^{5}$.

"We are never in the position to place certain indisputable sentences at the very top and then clearly and accurately display the whole chain of ideas, be it in logic of in physics, in biology or in philosophy. That which is unsatisfactory seeps through the whole of the realm of ideas, it is detectable in the first premises as in the later ones. It is of no use to be careful and supposedly renounce knowledge already gained in order to proceed from a tabula rasa and improve things henceforth, as Descartes had the audacity to try. Such attempts only end with masquerades of insight ...Our thinking is of necessity full of tradition, we are children of our time, even if we fight against it as we may; there are only ages which recognise this more clearly than others... We are like sailors who are forced to reconstruct totally their boat on the open sea with beams they carry along, by replacing beam for beam and thus changing the form of the whole. Since they cannot land they are never able to pull apart the ship entirely in order to build it anew. The new ship emerges from the old through continuous transformation ([Neurath, 1913, p. 457], quoted after [Cartwright et al., 1996, pp. 130-131]).

This pluralistic, non-foundational view of science makes Neurath an unlikely advocate of a technocratic and positivistic approach (see [O'Neill, 2003] who mentions the Frankfurt School's mistaken attacks on the left Vienna Circle).

\section{Science as Social Practice}

Anticipating Kuhn's insights by more than forty years (and Ludwik Fleck's by twenty $)^{6}$ Neurath emphasizes the social mechanisms at work in the emergence of scientific knowledge (cf. [Zolo, 1989, p. 45]). Already in 1915 Neurath had published an article on the history of optics

5 It is telling that Popper's preferred metaphor was the foundations of science being drilled into a swamp. 'The empirical basis of objective science has thus nothing "absolute" about it. Science does not rest upon rock-bottom. The bold structure of its theories rises, as it were, above a swamp. It is like a building erected on piles. The piles are driven down from above into the swamp, but not down to any natural or "given" base; and when we cease our attempts to drive our piles into a deeper layer, it is not because we have reached firm ground. We simply stop when we are satisfied that they are firm enough to carry the structure, at least for the time being' [Popper, 1959, p. 111].

6 The Genesis and Development of a Scientific Fact, (edited by T.J. Trenn and R.K. Merton, foreword by Thomas Kuhn) Chicago: University of Chicago Press, 1979. This is the first English translation of his 1935 book titled Entstehung und Entwicklung einer wissenschaftlichen Tatsache. Einführung in die Lehre vom Denkstil und Denkkollektiv Schwabe und Co., Verlagsbuchhandlung, Basel. 
where he noted that promising theories were discontinued but theories which could not explain certain experiences which had already been successfully explained by other theories were continued nevertheless. He saw the importance of generational conflicts ('often promising theories were dropped because the young are always eager to tamper with the work of the elders'), as well as the social norms that confer an advantage to the conformist as the innovators are marginalized: ' $[\mathrm{H}] \mathrm{ow}$ soon one senses the weakening effect of isolation. Thus one deserts the lonely, though perhaps auspicious, notions of an outsider, to join in the work in a way of thought that enjoys more support and has therefore better chances of greater scientific achievement... mostly through adaptation and selection, a kind of assimilation of whole generations takes place' ([Neurath, 1935], as cited in [Hegselmann, 1979, p. 41]) ${ }^{7}$.

When Popper published his book Logik der Forschung in 1935 (which was to become influential far beyond the circles of philosophers of science), Neurath (1935b) gave it a damaging review, already apparent in the title: 'Pseudorationalismus der Falsifikation'. Above all, he takes issue with Popper's criterion of falsification. In Neurath's view this principle is an attempt at philosophical absolutism, suppressing the 'plurivocality of the empirical sciences'. Hence 'falsificationism became no more acceptable than verificationism, since it led only to the same "logical absolutisation" of scientific method' ([Neurath, 1935b], cited after [Zolo, 1989 , p. 65]). He does not agree with Popper that negative experimental results (or an experimentum crucis) would falsify a theory. Such results could shake a researcher's confidence in a theoretical framework, but not automatically dictate its abandonment ([Neurath, 1935b], cited after [Zolo, 1989, p. 67]). Instead, Neurath uses the terms ‘corroboration' (Bewährung) and 'weakening' (Erschütterung) and argues that it is in many cases rational to hang on to a theory that in Popper's view is falsified if one regards the chances of future development of this theory as positive (but not the development of an alternative theory which at first sight is better equipped to explain the original theory). Popper himself was forced to admit as much in his later exchange with Kuhn when he said that a certain amount of dogmatism was useful for the development of science: 'I realized the opposite: the value of a dogmatic attitude: somebody had to defend a theory against criticism or it would succumb too easily, and before it had been able to make its contributions to the growth of science' ([Popper, 1979, p. 30], cited in [Zolo, 1989, p. 79]).

The importance of Neurath in this regard has been recently acknowledged by authors like Zolo [1989], Uebel [2000], O’Neil [2003] and Cartwright at al. [1996]. However, it did not come into the picture during the 'empiricist revolt' against Popperian philosophy of science during the early 1970 s, as is evident in the writings of the so-called Edinburgh school (Barnes, Bloor). 
Of course everything depends on the assumptions that are made in order to judge the potential of development. This leads back to one of Duhem's points about the importance of auxiliary assumptions. It also foreshadows the issue at stake in the later debate between Popper on one side and Lakatos and Kuhn on the other ${ }^{8}$. As Neurath points out, experimental scientists pay often more attention to confirming evidence rather than falsifying evidence, nowadays widely known as confirmation bias. What is more, Popper does not provide a historical account of how scientists make decisions about retaining or discarding hypotheses - but exactly this is what is required, according to Neurath. He thus formulated a research programme that became reality only decades later. As Zolo $[1989$, p. 68] notes, the ' $[r]$ etention or rejection of theories would remain a matter of decision for the scientific communities, and the decisions of such communities would be made on the basis of informal criteria varying from case to case'.

Thomas Kuhn saw individual scientists adhering to and operating according to a paradigm. Earlier, Ludwik Fleck used the term thought collective, and Lakatos preferred to speak of research programmes. Neurath had introduced the term encyclopedia to describe a scientist's 'stock of convictions'. Common to each of these frameworks is the assumption that a theory will not be abandoned automatically if anomalies emerge. In Neurath's words: 'Negative results can shake [the scientist's] confidence in an encyclopedia but not reduce it automatically to zero, so to speak, through the application of certain rules' ([Neurath, 1935b, p. 356], as quoted in [Hegselmann, 1979]) $)^{9}$. Like Kuhn after him, Neurath had more sympathy with the scientific establishment and did not share Popper's bias of favouring the challengers of existing theories ${ }^{10}$.

Perhaps most interesting in the context of the relation between expert knowledge and public policy making, where a higher status is accorded to research communities in the so called 'hard' or 'exact' sciences, Neurath alerted us to the fact that social scientists tend to believe that'physics and astronomy [are the] El Dorado of exactness and definitiveness, and they assume, frequently, that in this field any kind of contradictions are fatal to hypotheses' (cited in [Zolo, 1986, p. 94]). However, this is a myth according to Neurath. He points out that it might be easier to predict the outcomes of an election than the movements of meteors, and that the prediction of earthquakes was no more reliable than the prediction of wars or revolutions. Despite these insights it was still widely believed (a belief still shared by positivists today) that physics could be the model leading other disciplines to success.

8 See [Lakatos, 1976] distinction between progressive and degenerative research programmes.

9 The notion of encyclopedia emphasizes the open and circular character of knowledge.

10 For a vigorous defence of the Popperian spirit, see [Fuller, 2000]. 
Turning such conventional wisdom (as promoted, inter alia, by Popper and Hempel) on its head, Neurath argues that physics has a lot to learn from sociology. This is because sociology understands that what can be achieved in terms of scientific progress is only 'weak generalizations'. Sociologists are aware of the relativity of their results and the fact that they are bound to time and space. Sociology should 'be concerned much less with showing that [it] is able to obtain the same excellent results as those achieved by other sciences than with giving prominence to the fact that the bounds already recognized to exist for sociology exist also for all the other sciences' ([Neurath, 1936], as quoted in [Zolo, 1989, p. 98]) ${ }^{11}$. All sciences are dependent on ceteris paribus assumptions which are taken for granted. They need to be revealed, and, where appropriate, questioned. Therefore his advice to sociologists and physicists alike is as follows: 'instead of vainly attempting to follow [...] the example of physics, and to search for universal sociological laws, it would be better to follow in physics the example of a historicist sociology, i.e. to operate with laws which are limited to historical periods' (cited in [Ibid., p. 99]).

Social scientists, Neurath suggested, should abandon their search for discovering causes of social phenomena. Instead, they should limit themselves to the task of showing how certain events were 'emerging from' specific social aggregations [Ibid., p. 128]. Drawing on the examples of Machaivelli and Montesquieu's comparative political studies Neurath thinks these had much to commend in terms of understanding and predicting social change. In fact, this comparative social science inquiry is very much practiced in comparative studies of societies [Esping-Andersen, 1990; Hall, 1989; Hall and Soskice, 1979].

\section{Anti-Foundationalism}

Neurath was not blind to the methodological problems of the social sciences. He identified the method of causal analysis as a particular problem. Some sociologists were quite successful in demonstrating correlations between a limited number of elements. However, this was possible only at the exclusion of a great many of other elements that could have come into play. Hence the frequent use of clauses such as ceteris paribus.

11 This, of course, drew the ire of Popper. See his Poverty of Historicism where he writes: "[I]t is an important postulate of scientific method that we should search for laws with an unlimited realm of validity. If we were to admit laws that are themselves subject to change, change could never be explained by laws. It would be the admission that change is simply miraculous. And it would be the end of scientific progress; for if unexpected observations were made, there would be no need to revise our theories; the ad hoc hypothesis that laws have changed would 'explain' everything" [Popper, 1960, p. 103]. 
Neurath argues that it is impossible to study the general conditions under which the established correlations would continue to hold true. A sociologist should be interested in the analysis of these boundary assumptions and not quietly ignore them. Apart, social scientists should not seek to establish general 'laws' and 'causes' of social phenomena, 'but to evaluate in each individual case the kind of connection which linked certain phenomena to other particular phenomena' [Zolo, 1989, p. 128]. Abandoning the traditional view that any kind of prediction needs to be based on an understanding of causal mechanisms, Neurath argues that the aim of sociology as an empirical science should be the prediction of social change. As Zolo [1989, p. 129] put it, the task of the sociologist was 'to develop theoretical hypotheses which could allow him to understand and predict the behaviour of social groups on the basis of their past history'. Likewise, Cartwright et al. [1996, p. 244] argue that 'Neurath may not have cared about truth but he did care about effectiveness'.

But if causal analysis is ruled out as a method on which to base prediction, we are left with a problem. There is great variety of possible changes, including institutional, organizational and technological. How could we predict the invention of a technology if we are still incapable of inventing it? As Zolo [1989, p. 131] pointed out, to 'predict in advance Einstein's calculations on relativity, for example, one would require "anticipating" Einstein himself'. Neurath recognized the role played by chance alteration in initial conditions which has an influence of the further development of things. And he was acutely aware of the problem of reflexivity of social prediction: while the prediction of a solar eclipse does not influence the solar eclipse itself, the same is not true of predictions of share market performance.

In contrast to other social scientists, especially economists, Neurath was honest enough that the 'unpredictability within empiricism... was a bitter pill to swallow' [Ibid., p. 133]. Mainstream social scientists would console themselves with the reassurance that more and better information will be available in the future. Combined with better theoretical models we will make enough progress in this regard. For Neurath, unpredictability was part of social reality that could never be changed. He thus acknowledged that the social scientists are in no better position than the lay person when trying to make predictions. Sociologists 'are no better off than the man in the street as far as their predictions are concerned' (cited in [Ibid., p. 130]). The important task is thus to develop a language that will enable both experts and lay people to participate in decision making. This explains Neurath's keen interest in the development of Isotypes as a means of visual education.

Neurath's anti-foundationalism was complemented by a strong notion of science as a process based on intersubjectively shared understandings. The method to be used to achieve agreement in science as in wider society was negotiation: 'All knowledge claims must be conceived in such 
a way that people can discuss them by reference to intersubjective evidence' [Cartwright et al., 1996, p. 93]. This element of intersubectivity includes scientists and lay persons, as [Ibarra and Mormann, 2003, p. 242] say, '[f]or Neurath, a benchmark of good science was that it could in principle be explained to lay persons. Although this may sound like a cliché, Neurath took it seriously, as is shown by the immense work he invested in problems of public education, especially in developing his famous method of Wiener Bildstatistik' (see also [Fuller, 2000, p. 120]).

\section{Science and Policy Making}

We can now see how Neurath's theoretical and practical interests are interwoven and how his anti-foundationalist view of science corresponds to his view of policy making, despite some 'scientistic' overtones. These are due to his belief that value laden concepts would not be agreeable in political debates; he was convinced that it is more difficult to reach consensus or compromise on the basis of such concepts compared to 'thinner' concepts [O'Neill, 2003]. Neurath thus suggested that science offers the prospect of a universal language (he sometimes called it 'slang') that would enable people of different persuasions to communicate and co-operate with each other.

The way we conceptualize the relation between science and policy making has been influenced not only by the discussions of the Vienna Circle. Writing at the time of the revolutionary upheaval in Bavaria, Max Weber famously demarcated the different roles of scientists and politicians in modern democratic societies [Weber, 2020a; 2020b]. Neurath is a prime example for someone who sought to subvert this neat compartmentalization. His views as philosopher of science, social scientist, government minister, and policy advisor are intertwined, 'his intellectual work and political life evolved not separately but inextricably woven together. They formed a single passion' [Cartwright et al., 1996, p. 176-177].

Apart from the distinction between different value spheres (Wertsphären) in society, such as politics and science, Weber developed an argument about political decision making. He held that because the modern world is increasingly rationalized, this will manifest itself in the way decisions are reached. The ascendant class of experts within bureaucratic organizations makes politicians dependent on their advice. Weber argues that the classical roles of leadership (charismatic and traditional types) will become less apparent and be superseded by a legal rational type. Decisions are prepared by administrators working in the shades, unknown by the public at large. The politician who adopts the recommended policies essentially 'sells' them to the electorate without being able in every 
instance to check up on the details. The demands of the bureaucratic machinery are such that we will see the power transferred from politicians to experts. As Weber put it, the "political master finds himself in the position of the "dilettante" who stands opposite the "expert" facing the trained official who stands within the management of administration'.

Habermas picked up on this argument, introducing a tripartite distinction. Apart from the power of experts (which he calls technocracy), we still have to reckon with the old-style political dominance (which he calls decisionism). Both modes of decision making are incompatible with principles of democratic societies and broader Enlightenment aspirations. Hence the need for a democratic mode of decision making [Habermas, 1971; Irwin, 1995; Jasanoff, 1990]. Drawing on Max Weber and Carl Schmitt, Habermas [1971, pp. 63-64] describes the technocratic model as one in which the politician 'becomes a mere agent of a scientific intelligentsia, which, in concrete circumstances, elaborates the objective implications and requirements of available techniques and resources as well as of optimal strategies and rules of control'. In contrast, in the decisionistic model 'political action cannot rationally justify its own premises. Instead, a decision is made between competing value orders and convictions, which escape compelling arguments and remain inaccessible to cogent discussion'. Habermas argues that decisionism reigns in contemporary mass democracies but that it is deficient because of its lack of public involvement. The public is purely in an acclamatory position to legitimate decisions, not to discuss them. Referring to Dewey, Habermas envisages a pragmatist solution where the separation between expert and politician is replaced by a critical interaction and scientifically informed public discussion. At the time Habermas wrote this, there were few if any high-profile controversies around technical and scientific developments. But the past decades have seen many of them, and also attempts at bridging the gulf between lay and expert discourses. Now the public is involved to a greater degree, if only virtually (via the media, opinion polls and elections). What is more, structural changes in modern societies have led to a much wider knowledge base [Stehr, 1994]. Politicians nowadays, pace Weber, often have to know intricate details of policies and their implications if they want to persuade a knowledgeable public.

I now turn to the literature on public policy and examine Neurath's hope that social engineering might provide solutions to practical problems of policy-making. 


\section{Political Science Approaches: The Linear Rational Model and Beyond}

Apart from contributions in social and political theory there has been a welter of theories and models from scholars working in the relatively young discipline of Political Science. Important contributions were made mainly by US political scientists, initially in the field of public policy and later in the field of international relations. Early well-known contributions by [Lasswell and Kaplan, 1950] depicted a linear-rational model of policy making ${ }^{12}$. It follows an enlightenment model of politics in which scientific knowledge helps solving societal problems. As science produces true and valid knowledge this can be used in the political process where it produces the 'right' political decisions and effectively resolves politically motivated debates. We can see how Neurath's motive lingers on, i.e. the hope that a science-based solution will be agreeable to warring parties since it transcends the ideological (metaphysical) differences. However, Neurath's central point has been lost, namely that there is no scientific certainty on which to base such decisions. This point has been developed with great force in the field of Science and Technology Studies (STS), where the debates around regulatory science, risk society and public engagement have provided much evidence in support of Neurath [Beck, 1992; Demortain, 2017; Funtowicz and Ravetz, 1993; Grundmann and Stehr, 2012; Strassheim and Kettunen, 2014; Wynne, 1992].

This literature also tells us that science, far from uniting polities, can become a force of polarization. The discourse on climate change is a case in point. Dan Sarewitz [2004] has shown how science can be subject to becoming politicized in such controversies. This is so because science provides arguments to different sides of the debate, to different social groups and interests. Scientific facts are picked to bolster particular interests and normative frameworks. He concludes that the values underlying environmental controversies should be fully articulated and adjudicated through political means. Imposing 'the science' onto such debates will resolve nothing (see [Hulme, 2009] for a similar argument). Instead, using 'the science' to silence political opponents will not win them over but rather increase polarization. Policy controversies around COVID-19 might provide similar lessons. Rather than assuming science could tell people what to do, broad public support for, and trust in policies will prove more effective.

12 This model covers technological applications of scientific research as well. Godin [2006] has argued that the 'linear model' is a stylized artefact which emerged out of various institutional practices (US government accounting schemes and OECD statistical definitions). It cannot be ascribed to single individuals such as Bush [1945], although this is common practice. 
It might be useful to distinguish between two strands in the public policy literature, a rationalist and a pragmatic strand. The rationalist approach tries to base political decisions on the best available knowledge whereas the pragmatist approach aims at negotiated solutions that work. We shall see where Neurath ends up on this map.

Charles Lindblom's classic description of public policy as the 'Science of muddling through' can be read as a pamphlet in favour of a pragmatist approach. Lindblom contrasts the rational approach (which involves a huge information collection exercise plus a systematic comparison of available alternatives of action) with a more modest approach where the policy maker only considers a few policy alternatives (most of which will be familiar to him from past controversies), relying on a record of 'past experience with small policy steps to predict the consequences of similar steps extended into the future' [Lindblom, 1959, p. 79]). Echoing [March and Simon's, 1985] bounded rationality thesis, Lindblom argues that the first of these approaches is impossible with complex problems since limitations of time and resources (monetary, intellectual, and informational) are overwhelming. He even suggests that in practice, administrators are not advised to act on the second model but to restrict their consideration of policy alternatives to just a few. It is therefore curious that 'the literatures of decision making [...] and public administration formalize the first approach and not the second' [Ibid., p. 80]. In a later article Lindblom returned to the topic, defending the second approach which he now calls 'disjointed incrementalism'. His argument rests on the case that we will never achieve a'full picture', or a synoptic view of all relevant elements (values, information, factors, causes...) that are prior to a decision. Instead, we have to proceed from a grossly incomplete analysis but do this in a conscious way. It is of no help to appeal to the ideal of synoptic analysis as it will lead to worse outcomes compared to decision makers who are conscious of the limitations and muddle open-eyed, so to speak. As he put it, 'a conventional synoptic (in aspiration) attempt to chose and justify the location of a new public housing unit by an analysis of the entirety of a city's land needs and potential development patterns always degenerates at least into superficiality if not fraud. A disjointed incremental analysis can do better' [Lindblom, 1979, p. 519].

This sounds very different to what Neurath had hoped for the role of a unified science, and its influence on policy making in a socialized economy, via social engineering. On the other hand, incrementalism is very much in line with Neurath's emphasis of the impossibility of an overall deductive framework which operates in science, and a fortiori also in society. Lindblom's policy-makers are Neurath's sailors. 


\section{Roles of Academics, Roles of Policy Makers}

Echoing Weber's separation of politics and science, another strand in the literature has developed the view that politics and science are at odds with each other, mainly for epistemological reasons and language barriers. To take two influential authors, we mention the two communities model, developed, inter alia, by Caplan [1979]. This casts doubt on the concept of a linear rational model and sees the relation between science and politics as difficult. Science and politics are characterized by different logics and cultures ${ }^{13}$. Whilst the scientist wants to arrive a the truth, the politician is concerned about power. Asserting the theory of functional differentiation, Luhmann [1995] makes a more basic point about the problematic nature of communication between social systems. Communication between politics and science is problematic, or 'highly improbable'.

Whenever ideas have become institutionalized in policies and therefore have become real, it seems only natural that what has happened had to happen. In other words, the link between knowledge and politics now seems unproblematic. The link between knowledge and power appears inevitable. It is the task of the historian and critical social scientist to unravel this apparent inevitability. Michel Foucault thus conceived as knowledge and power as inseparably interlaced, coining the term knowledge/power. This contrasts with the above analysis where the roles of academics and policy makers are different and where actors from these two fields inhabit different epistemic universes. Based on this view one would assume that it is unlikely that these roles will intertwine easily. Unlikely does not mean impossible, but the possibility of such 'meetings' needs to be investigated carefully.

Hernes [2008] has given a description of his commuting experience between the world of (social) science and politics. He notes that politicians and social scientists show mutual benign neglect for each other, 'politicians funding research but taking little interest in the results; researchers describing the world, but not really expecting much in terms of changing it'. Hernes goes on to construct a typology of the two roles ${ }^{14}$.

13 The two communities model has been superseded by policy network approaches [Heclo, 1974; Rhodes and March, 1992] and discourse coalitions [Hajer, 1995]. Here, a close exchange of information between actors of different social subsystems is postulated (including representatives from industry, science, administration, and the public). They participate in a public discourse and at times also cooperate within less visible networks in order to influence political decisions. They confront another set of actors who support different interests, values, and political goals.

14 Without going into too much detail of his typology and some problems associated with it, suffice it to say that he seems to adhere to a rather naïve Popperian view that scientists would reject a theoretical model if empirical evidence does not conform to it [Hernes, 2008, p. 262]. 
He suggests that the first step in the work of a social scientist is always an observation in need of explanation whereas the politician starts with the definition of a political issue that needs to be addressed (and remedied). It is therefore 'the aim of the scientist is to explain reality, the aim of the politician to turn something into reality' [Hernes, 2008, p. 262]. The politician needs 'levers of action' in order to change reality - moreover, a skilled politician should be able to foresee side effects and unintended consequences. Hernes concludes with the remark that the task of the scientist is to 'invent explanations and validate them' whereas the task of the politician is to invent interventions and implement them' [Ibid., p. 263]. It would be interesting to carry the argument one step further and see what happens when scientists (or other nonpoliticians) try to affect political changes and are savvy enough to understand the nature of the political process. Following Marx's dictum ('The philosophers have only interpreted the world, in various ways. The point, however, is to change it') many have tried to do so, not only Marxists. Scientists working in nearly all disciplines, from Anthropology to Zoology, have made attempts to influence political outcomes through their open or hidden advocacy. So have business and civil society groups, at times working closely with scientists, at times providing knowledge claims themselves.

Using Neurath's experience as a social scientist turned politician, and social scientist again, we can identify a role hybrid of scientist and politician, revising the role Hernes assigned to the scientist as an exclusive cognitive being. It would seem that the more scientists understand about the nature of the political process the more they are tempted to smuggle research results into political practice, if they are given the opportunity [Varoufakis, 2017]. However, such attempts bring their own problems. Scientists turning policy-makers will be caught by a different logic of social action, the logic of power and politics. They may have an easy ride in quiet times; but they can also be exposed to considerable risks in turbulent times, as the example of Neurath himself demonstrates. But we also need to distinguish between different roles that are available [Grundmann, 2018; 2021; Pielke Jr., 2007]. There is the minister, the science advisor, the advocate, or the commentator: all imply different functions in society, different visibility and influence, and different access to power.

Neurath was a pioneer in analyzing science as a social practice. His understanding of science was closely related to his politics, since the prospects for a better society relied on scientists speaking in a clear language to the public. The latter point has been taken up by science communication scholars. Still, we may disagree with his politics, and the need for a unified science, but at least he was clear about his aims. 


\section{References / Список литературы} 1992.

Beck, 1992 - Beck, U. Risk Society: Towards a New Modernity. London: Sage,

Bush, 1992 - Bush, V. Science: the Endless Frontier. Washington D.C., 1945.

Caplan, 1979 - Caplan, N. "The Two-Communities Theory and Knowledge Utilization”, American Behavioral Scientist, 1979, vol. 22 (3), pp. 459-470.

Cartwright et.al., 1996 - Cartwright, N., J. Cat, L. Fleck, T.E. Uebel. (eds.) Otto Neurath. Philosophy Between Science and Politics. Cambridge: Cambridge University Press, 1996.

Demortain, 2017 - Demortain, D. "Expertise, Regulatory Science and the Evaluation of Technology and Risk: Introduction to the Special Issue”, Minerva, 2017, vol. 55, no. 2, pp. 139-159.

Esping-Andersen, 1990 - Esping-Andersen, G. The Three Worlds of Welfare Capitalism. Princeton, N.J.: Princeton University Press, 1990.

Fuller, 2000 - Fuller, S. Thomas Kuhn: A Philosophical History for Our Times. Chicago: The University of Chicago Press, 2000.

Funtowicz and Ravetz, 1993 - Funtowicz, S.O. and Ravetz, J.R. "Science for the Post-Normal Age”, Futures, 1993, vol. 25 (7), pp. 735-755.

Godin, 2006 - Godin, B. "The Linear Model of Innovation. The Historical Construction of an Analytical Framework”, Science, Technology, and Human Values, 2006, vol. 31, pp. 639-667.

Grundmann, 2021 - Grundmann, R. Making Sense of Expertise. New York, NY: Routledge, 2021. (In print)

Grundmann, Stehr, 2012 - Grundmann, R., and Stehr, N. The Power of Scientific Knowledge: From Research to Public Policy. Cambridge: Cambridge University Press, 2021.

Grundmann, 2018 - Grundmann, R. “The Rightful Place of Expertise”, Social Epistemology, 2018, vol. 32 (6), pp. 372-386.

Habermas, 1971 - Habermas, J. "Technology and Science as Ideology", in: Toward a Rational Society: Student Protest, Science, and Politics, Boston: Beacon Press, 1971, pp. 81-122.

Hajer, 1995 - Hajer, M.A. The Politics of Environmental Discourse: Ecological Modernization and the Policy Process. Oxford: Clarendon Press, 1995.

Hall, Peter A. 1989. The Political Power of Economic Ideas: Keynesianism across Nations. Princeton, NJ: Princeton University Press.

Hall and Soskice, 2001 - Hall, P.A., and Soskice, D. Varieties of Capitalism: The Institutional Foundations of Comparative Advantage. Cambridge, MA: Harvard University Press, 2001.

Heclo, 1974 - Heclo, H. "Issue Networks and the Executive Establishment”, The Oxford Handbook of Classics in Public Policy and Administration (June 2020), pp. 1-12.

Hegselmann, 1979 - Hegselmann, R. "Otto Neurath - Empirischer Aufklärer Und Sozialreformer”, in: Otto Neurath. Wissenschaftliche Weltauffassung, Sozialismus Und Logischer Empirismus. Frankfurt a.M.: Suhrkamp, 1979, pp. 7-78.

Hernes, 2008 - Hernes, G. "The Interface Between Social Research and Policy Making”, European Sociological Review, 2008, vol. 24 (2), pp. 257-265. 
Hulme, 2009 - Hulme, M. Why We Disagree About Climate Change: Understanding Controversy, Inaction and Opportunity. Cambridge University Press, 2009.

Ibarra and Mormann, 2003 - Ibarra, A. and Mormann, T. 2003. "Engaged Scientific Philosophy in the Vienna Circle: The Case of Otto Neurath", Technology in Society, 2003, vol. 25, pp. 235-247.

Irwin, 1995 - Irwin, A. Citizen Science: A Study of People, Expertise and Sustainable Development. London: Routledge, 1995.

Jasanoff, 1990 - Jasanoff, S. The Fifth Branch: Science Advisers as Policymakers. Cambridge, MA: Harvard University Press, 1990.

Lakatos, 1976 - Lakatos, I. Proofs and Refutations. Cambridge: Cambridge University Press, 1976.

Lasswell and Kaplan, 1950 - Lasswell, H. and Kaplan, A. Power and Society: A Framework for Political Inquiry. New Haven: Yale University Press, 1950.

Lindblom, 1959 - Lindblom, C. "The Science of 'Muddling Through", Public Adinistration Review, 1959, vol. 19, pp. 79-88.

Lindblom, 1979 - Lindblom, C.E. 1979. “Still Muddling, Not Yet Through”, Public Administration Review, 1979, vol. 39 (6), p. 517.

Luhmann, - Luhmann, N. Social Systems. Stanford, CA: Stanford University Press, 1995.

March and Simon, 1958 - March, J.G. and Simon, H.A. Organizations. New York: John Wiley \& Sons, 1958.

McGuinness, 1987 - McGuinness, B.F. 1987. Unified Science: The Vienna Circle Monograph Series Originally Edited by Otto Neurath, Now in an English Edition. Dordrecht: Reidel, 1987.

Neurath, 1913 - Neurath, O. "Probleme Der Kriegswirtschaftslehre”, Zeitschrift für die gesamte Staatswissenschaft, 1913, vol. 69 (3), pp. 438-501.

Neurath, 1931 - Neurath, O. "Soziologie Im Physikalismus", Erkenntnis, 1931, vol. 2 (1), pp. 393-431.

Neurath, 1933 - Neurath, O. Einheitswissenschaft und Psychologie. Wien: Gerold \& Co, 1933.

O’Neill, 1933 - O’Neill, J. “Unified Science as Political Philosophy: Positivism, Pluralism and Liberalism", Studies in History and Philosophy of Science Part A., 1933, 34 (3), pp. 575-596.

Pielke, 2007 - Pielke Jr., R. The Honest Broker. Cambridge: Cambridge University Press, 2007.

Popper, 1959 - Popper, K.R. The Logic of Scientific Discovery. London: Hutchinson, 1959. 1960.

Popper, 1960 - Popper, K.R. The Poverty of Historicism. London: Routledge,

Rhodes and March, 1992 - Rhodes, R.A.W. and March, D. "New Directions in the Study of Policy Networks", European Journal of Political Research, 1992, vol. 21 (1-2), pp. 181-205.

Sarewitz, 2004 - Sarewitz, D. "How Science Makes Environmental Controversies Worse”, Environmental Science and Policy, 2004, vol. 7 (5), pp. 385-403.

Skocpol, 1979 - Skocpol, T. States and Social Revolutions: A Comparative Analysis of France, Russia, and China. Cambridge University Press, 1979.

Stehr, 1994 - Stehr, N. Knowledge Societies. London: Sage, 1994. 
Strassheim and Pekka, 2014 - Strassheim, H., and Kettunen, P. "When Does Evidence-Based Policy Turn into Policy-Based Evidence Configurations, Contexts and Mechanisms”, Evidence and Policy, 2014, vol. 10 (2), pp. 259-277.

Uebel, 2000 - Uebel, T. Vernunftkritik Und Wissenschaft. Otto Neurath Und Der Erste Wiener Kreis. New York, NY: Springer, 2000.

Varoufakis, 2017 - Varoufakis, Y. Adults In The Room: My Battle With Europe's Deep Establishment. London: Penguin, 2017.

Weber, 2020a - Weber, M. "Politik Als Beruf (1919)", in: H.-P. Müller and S. Sigmund (eds.) Max Weber-Handbuch: Leben - Werk - Wirkung. Stuttgart: J.B. Metzler, 2020, pp. 265-270.

Weber, 2020b - Weber, M.“Wissenschaft Als Beruf (1917/1919)”, in: H.-P. Müller and S. Sigmund (eds.) Max Weber-Handbuch: Leben - Werk - Wirkung. Stuttgart: J.B. Metzler, 2020, pp. 259-264.

Wynne, 1992 - Wynne, B. "Misunderstood Misunderstanding: Social Identities and Public Uptake of Science", Public Understanding of Science, 1992, vol. 1, pp. 281-304.

Zolo, 1989 - Zolo, D. Reflexive Epistemology. Dordrecht: Springer Netherlands, 1989. 